\title{
Allelopathic potential of Cyperus rotundus L. extracts on germination and cowpea seedling establishment
}

\author{
João Alves Ferreira PEREIRA ${ }^{1,2}$, Tatiana Maria da SILVA ${ }^{1,2}$, Andreza Raquel Barbosa de FARIAS ${ }^{1,2}$, \\ Alexandre Bosco de OLIVEIRA ${ }^{1,2^{*}}$
}

\author{
${ }^{1}$ Programa de Pós-Graduação em Agronomia (Fitotecnia), Universidade Federal do Ceará, Fortaleza, CE, Brasil. \\ ${ }^{2}$ Departamento de Fitotecnia, Universidade Federal do Ceará, Fortaleza, CE, Brasil. \\ *Autor para correspondência. E-mail: aleufc@gmail.com
}

Recebido em maio/2017; Aceito em fevereiro/2018.

\begin{abstract}
This study aimed to investigate the allelopathic effects of Cyperus rotundus L. extracts on seed germination and early development of seedlings of Vigna unguiculata L. Walp. Alcoholic extracts at concentrations of $0,1.5 \%, 3 \%, 4.5 \%, 6.0 \%, 7.5 \%$, and $9.0 \%$ were obtained by crushing $C$. rotundus $\mathrm{L}$. leaves used to moisten the "germitest" paper sheets. The data were subjected to analysis of variance and also both Tukey and Kruscal-Wallis tests were carried out at $5 \%$ for the data means. The first germination count, germination speed index, root length, shoot length, and dry root weight of cowpea were parametrically analyzed. The only variable with significance was first germination count. The germination reducted in relation to the control treatment around $10 \%$. Thus, in the conditions used in this research, alcoholic extracts of $C$. rotundus L. did not affect either seed germination or early growth of cowpea seedlings.
\end{abstract}

Keywords: nut grass, allelopathy, interference, weeds.

\section{Potencial alelopático de extratos de Cyperus rotundus L. na germinação e estabelecimento de plântulas de feijão-caupi}

RESUMO: Este trabalho investigou os efeitos alelopáticos de extratos de Cyperus rotundus L. na germinação de sementes e crescimento inicial das plântulas de Vigna unguiculata L. Walp. Extratos alcoólicos nas concentrações $0 ; 1,5 \% ; 3,0 \% ; 4,5 \% ; 6,0 \% ; 7,5 \%$ e 9,0\%, obtidos a partir da trituração de folhas de $C$. rotundus L. foram utilizados para umedecimento das folhas de papel toalha "germitest". Os dados foram submetidos a análise de variância pelo $\mathrm{F}$ e as médias comparadas pelos testes de Tukey e Kruscal-Wallis, ambos a 5\% de probabilidade. A primeira contagem de germinação, índice de velocidade de germinação, comprimento de raiz, comprimento da parte aérea e massa seca da raiz do feijão-caupi foram analisados de forma paramétrica, sendo constatado que apenas houve significância na variável primeira contagem e uma redução na germinação em relação ao tratamento controle em torno de $10 \%$. Nas condições em que essa pesquisa foi realizada, os extratos alcoólicos de $C$. rotundus L. não afetam a germinação de sementes e crescimento inicial das plântulas de feijãocaupi.

Palavras-chave: tiririca, alelopatia, interferência, plantas daninhas.

\section{INTRODUCTION}

Weeds can be defined as all plants whose advantages have not yet been discovered or those that negatively interfere with man's objectives (FISHER, 1973; SILVA et al., 2015). It is worth mentioning that the negative effects caused by the presence of weeds should not be attributed exclusively to competition, but rather to a total resultant of environmental pressures such as competition, interference at harvest, allelopathy, etc. (KARAM et al., 2007).

Among the weeds, Cyperus rotundus L. is one of the most important due to its rapid reproduction, characterized by vegetative propagation through bulbs, rhizomes, and especially, tubers, as well as the difficulty of its control (MILES et al., 2002; JAKELAITIS et al., 2003; SILVA et al., 2015). This extensive presence of vegetative structures in the soil can benefit the weed in the competition for water and nutrients. In addition, this weed can release allelopathic substances into the soil and is responsible for huge productivity losses in several crops such as cucumber (Cucumis sativus L.), corn (Zea mays), tomato
(Lycopersicum esculentum Mill.), radish (Raphanus sativus L.), wheat (Triticum aestivum L.), cowpea (Vigna unguiculata L.) and lettuce (Lactuca sativa L.) (MAZZAFERA, 2003; ZANARDI et al., 2016; KAEFER; SOUZA et al., 2016; FORTES, 2016).

Allelopathy is defined as any process involving secondary metabolites (allelochemicals), which plants and microorganisms produce and release into the environment that interferes with the development of natural or implanted biological systems, either positively or negatively (MARASCHIN-SILVA; AQUILA, 2006; MAIRESSE et al., 2007; SILVA et al., 2011).

Inhibitory effects on plant germination and growth are often associated with allelopathy. Several authors have evaluated the effect of the plant extracts of $C$. rotundus with allelopathic effect on germination and initial growth of several crops, such as common bean (COELHO et al., 2014), tomato, cabbage, lettuce, and radish (GUSMAN et al., 2011), and corn (SCHEREN et al., 2014). In fact, this process is extremely important in understanding plant 
interactions in natural environments and agroecosystems (FRITZ, 2007). Germination is one of the parameters of the physiological quality of the seed. The objective of a germination test is to determine the maximum germination potential of a seed lot; the observed value is used to compare the quality of different lots and to estimate the sowing value (quantity of seeds) in the field (BRASIL, 2009).

Substances available in nature produced by plants or even by microorganisms can offer new and excellent opportunities for diversification of weed control in agriculture, reducing or eliminating environmental contamination, preserving natural resources, and ensuring the availability of agricultural products with high quality, devoid of residual contaminants (SOUZA FILHO, 2006).

Cowpea (Vigna unguiculata L. Walp.) is very important, both as food and as a generator of employment and income. It is rich in protein, minerals, and fibers (FROTA et al., 2008) and is a basic food component of rural and urban populations in the North and Northeast regions of Brazil (FREIRE FILHO, 2011; COSTA et al., 2017). In the field, the crop can be affected by numerous biotic and abiotic factors especially competition and the effect of allelopathic substances caused by weeds, which can result in a reduction of the initial plant stand, and consequently reduce yields.

The present work investigated the allelopathic effects of alcoholic extracts of $C$. rotundus $\mathrm{L}$. on seed germination and initial growth of cowpea seedlings.

\section{MATERIAL AND METHODS}

The experiment was carried out at the Seed Analysis Laboratory of the Federal University of Ceará, belonging to the Department of Plant Science of the CCA/UFC, Fortaleza, Ceará, Brazil. The leaves of $C$. rotundus L. used in the experiment were collected in a vegetable growing area located in the Teaching Garden of the Department of Plant Science of the CCA/UFC.

The extracts were prepared with hydrated ethyl alcohol $(92.8 \%)$ at concentrations $(\mathrm{w} / \mathrm{v})$ of $0.0,1.5 \%, 3.0 \%, 4.5 \%$, $6.0 \%, 7.5 \%$, and $9.0 \%$. These concentrations were obtained by weighing the fresh leaves and then crushing the leaves in a blender in relation to the alcohol volume, thus obtaining a $\mathrm{w} / \mathrm{v}$ ratio. For the $1.5 \%$ concentration, $1.5 \mathrm{~g}$ of fresh leaves were used for each $100 \mathrm{~mL}$ of alcohol, and so on for the other concentrations. The extracts obtained were impregnated in the germitest paper sheets, which were used as substrate, $20 \mathrm{ml}$ of each extract was placed on each germitest sheet and dried at room temperature until the solvent used was evaporated.

Seeds of cowpea, cultivar seventy, used in the evaluations were previously disinfested with sodium hypochlorite $(2 \%)$ for approximately $3 \mathrm{~min}$. Then, they were washed in running water and placed on the germination paper ("germitest") to perform the evaluations.

During the experiments, the germinating paper sheets were moistened with a standard amount of water, to avoid prostrate development due to the difference in water availability. The parameters observed and evaluated were as follows:

The germination test was conducted following the Rules for Seed Testing (BRASIL, 2009). Three sheets of "germitest" paper were used as substrate, moistened with distilled water in the volume 2.5 times the mass of the dry paper. The four replicates of 50 seeds per treatment were organized in roll form and kept in plastic bags in the germinator, at $25^{\circ} \mathrm{C}$.

The first germination count, conducted together with the germination test, was the count of the normal seedlings present on the eighth day after the germination test was installed (BRASIL, 2009).

The germination speed index was performed in conjunction with the germination test, in which, starting the third day after sowing, counts were performed on the number of seeds germinated daily, until the eighth day. The rate of germination was calculated according to Maguire (1962);

The seedling evaluation was carried out on the eighth day after the installation of the experiment in which 25 seedlings from the germination test had their shoot and root length measured. Then the parts were packed in kraft bags and dried at $80{ }^{\circ} \mathrm{C}$ for 24 hours in a forced air circulation incubator and subsequently weigh on an analytical balance $(0.001 \mathrm{~g})$ to determine the mass of dry matter (MARCOS FILHO, 1994).

The data were submitted to tests of normality and homogeneity of variances. When they met these assumptions, the data were submitted to analysis of variance, using the Tukey test $(5 \%)$ to compare the means. If the data did not meet at least one of the assumptions, they were submitted to Kruscal-Wallis nonparametric test (5\%).

\section{RESULTS}

The parameters of physiological germination $(\mathrm{G})$ and dry shoot mass (DSM) were analyzed in a non-parametric manner, as they did not present normality in the data even after being transformed. Table 1 gives the averages for each treatment. Both the germination and the dry shoot mass did not present significant difference by the of Kruskal-Wallis test, with significance level at 5\%.

Although there was no statistical difference, the highest concentrations of the extract $(7.5$ and $9.0 \%)$ reduced the percentage of germination compared to the treatment with distilled water (control), reaching 88.0 and $84.0 \%$ germination, respectively (Table 1).

Table 1. Seed Germination (G) and dry shoot matter (DSM) of cowpea seedlings submitted to different concentrations of alcoholic extract of Cyperus rotundus $\mathrm{L}$.

Tabela 1. Germinação $(G)$ de sementes e matéria seca da parte aérea (MSPA) de plântulas de feijão-caupi submetidas a diferentes concentrações de extrato alcoólico de Cyperus rotundus L.

\begin{tabular}{ccc}
\hline Treatment & G $(\%)$ & SDM $(\mathrm{g})$ \\
\hline Concentration $(\%)$ & Mean & Mean \\
\hline 0.0 & $93.0 \mathrm{a}^{1}$ & $0.0964 \mathrm{a}$ \\
1.5 & $90.0 \mathrm{a}$ & $0.0887 \mathrm{a}$ \\
3.0 & $90.5 \mathrm{a}$ & $0.0944 \mathrm{a}$ \\
4.5 & $87.5 \mathrm{a}$ & $0.0934 \mathrm{a}$ \\
6.0 & $88.0 \mathrm{a}$ & $0.0957 \mathrm{a}$ \\
7.5 & $88.0 \mathrm{a}$ & $0.0935 \mathrm{a}$ \\
9.0 & $84.0 \mathrm{a}$ & $0.0827 \mathrm{a}$ \\
\hline CV $(\%)$ & 5.23 & 7.48 \\
\hline
\end{tabular}

${ }^{1}$ médias seguidas de letras iguais nas colunas não diferem entre si pelo teste não paramétrico de Kruskal-Wallis, com nível de significância a 5\%.

${ }^{1}$ means followed by equal letters in the columns do not differ by KruskalWallis non-parametric test, with significance level at $5 \%$. 
The data of the first germination count (FGC), germination velocity index (GSI), root length (RL), shoot length (SL), and dry root matter (DRM) of the cowpea were analyzed parametrically and the result of significance are shown in Table 2. The first germination count was the only variable with significant difference. The other variables did not present a significant difference $(\mathrm{p}<0.05)$.

The vigor of the seeds was evaluated in this experiment by the first germination count, presenting a decreasing quadratic behavior, exposing a $\mathrm{R}^{2}$ of $70 \%$ of adjustment (Figure 1).

Table 2. Analysis of variance of the first germination count (FGC), germination speed index (GSI), root length (RL), shoot length (SL), and dry root mass (DRM) of cowpea seedlings under different concentrations of alcoholic extract of Cyperus rotundus L.

Tabela 2. Resumo da análise de variância da primeira contagem de germinação (PCG), índice de velocidade de germinação (IVG), comprimento da raiz (CR), comprimento da parte aérea (CPA) e massa seca da raiz (MSR) de plântulas de feijão-caupi sob diferentes concentrações de extrato alcoólico de Cyperus rotundus L.

\begin{tabular}{lcccccc}
\hline \multirow{2}{*}{ FV } & \multicolumn{6}{c}{ Mean squares } \\
\cline { 2 - 7 } & GL & FGC & GSI & RL & SL & RDM \\
\hline Rep. & 3 & $5435859^{\text {ns }}$ & $0.57^{\text {ns }}$ & $0.822^{\text {ns }}$ & $0.09^{\text {ns }}$ & $0.000005^{\text {ns }}$ \\
Conc. & 6 & $1711964^{*}$ & $1.05^{\text {ns }}$ & $0.988^{\text {ns }}$ & $1.03^{\text {ns }}$ & $0.000004^{\text {ns }}$ \\
Error & 18 & 4666790 & 0.54 & $1 ., 117$ & 0.62 & 0.000004 \\
Total & 27 & - & - & - & - & - \\
\hline CV & - & 12,9 & 5,3 & 6,8 & 8,6 & 9,6 \\
\hline
\end{tabular}

FV: fatores de variação; GL: grau de liberdade; repet.: repetição; conc.: concentração; CV: coeficiente de variação; ${ }^{\text {ns, }}$ *, respectivamente, não significativo, significativo a $5 \%$ de probabilidade de erro pelo teste $\mathrm{F}$ da análise de variância (ANOVA).

VF: variation factors; DF: degree of freedom; repet.: repetition; conc concentration; $\mathrm{CV}$ : coefficient of variation; ns, *, respectively, not significant, significant at $5 \%$ probability of error by the $\mathrm{F}$ test for the analysis of variance (ANOVA)

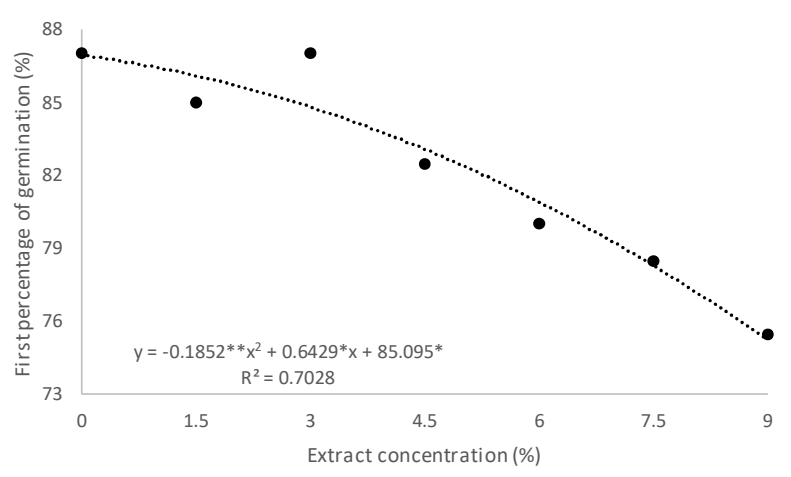

Figure 1. First percentage of germination of cowpea seeds submitted to different concentrations of alcoholic extract of the leaf of Cyperus rotundus $\mathrm{L} .{ }^{*}$, ** significance, respectively, 1 and $5 \%$ by the test $\mathrm{F}$ with $5 \%$ probability of error.

Figura 1. Primeira contagem da germinação (PCG) de sementes de feijão-caupi submetidas a diferentes concentrações de extrato alcoólico da folha de Cyperus rotundus L. *, ** significância, respectivamente, 1 e $5 \%$ pelo teste $\mathrm{F} 5 \%$ de probabilidade de erro.

\section{DISCUSSION}

The lack of statistical difference in seed germination could be explained by the dilution of the concentrations during the development of the experiment. A methodology must be found that maintains the initial concentrations until the end of the experiment. Similar results were observed by several authors, who found that alcoholic or aqueous extracts do not exert a significant effect on the germination of seeds (PINA-RODRIGUES; LOPES, 2001; MAZZAFERA, 2003; OLIVEIRA et al., 2004; BORTOLINI; FORTES, 2005). Different results were demonstrated in tests performed by Coelho et al. (2014) when evaluating the effect of plant extracts of $C$. rotundus $\mathrm{L}$. and Bidens pilosa $\mathrm{L}$. on germination and initial growth of kidney beans. According to these authors, ethanolic extracts of both C. rotundus L. and Bidens pilosa L. inhibit the germination of kidney bean seeds.

Germination is less sensitive than seedling growth to allelochemicals. However, the experimental quantification is much simpler, because for each seed the phenomenon is obvious, it either germinates or it does not germinate. In this context, allelopathic substances can induce the appearance of abnormal seedlings, and necrosis of the radicle is one of the most common symptoms (FERREIRA; AQUILA, 2000).

The effect of the ethanolic extract of the weeds Cyperus rotuntus, Brachiaria decumbens, Commelina benghalensis, and Cymbopogon winterianus on the germination of Phaseolus vulgaris seeds was similar to those found in the present experiment. The variables of germination and germination speed index were not influenced by the presence of extracts. However, the radicle and hypocotyl length were influenced by the presence of allelochemicals from the donor species (MELHORANÇA FILHO et al., 2011).

As mentioned previously, the same response was observed in the dry shoot mass (DSM) variable, where no significant differences between treatments were observed.

The seeds that were treated with the alcohol extract concentrations of $C$. rotundus L. above $4.5 \%$ had the lowest percentages of the first germination count, at $76 \%$, achieved with the use of the $9.0 \%$ concentration of the extract. This fact indicates that even though the germination was not affected by the highest concentrations, it affected the vigor of the cowpea seeds, represented here by the first germination count. It should be noted that a low seed vigor may result in a lower percentage or emergence under adverse field conditions (PÁDUA et al., 2010).

The allopathic effect may lead to changes in the distribution of germination, from normal distribution of kurtosis, in the simplest situations. It can generate erratic distributions, lengthening the curve through the time axis, or a complex pattern of seed germination distribution due to informational noise. Thus, the germination should be monitored daily or in periods less than 24 hours (LABOURIAU; AGUDO, 1987).

The studies of allelopathic effects and identification of the plants that possess it are very import, both in the use of agricultural cultivars capable of inhibiting weeds, and in determining the most appropriate cultivation and management practices (CARVALHO et al., 1996).

\section{CONCLUSIONS}

Under the conditions in which this research was carried out, the alcoholic extracts of $C$. rotundus $\mathrm{L}$. did not affect the seed germination and initial growth of the cowpea seedlings, to the point of damaging the establishment of the crop. 


\section{ACKNOWLEDGMENTS}

We thank Prof. Sebastião Medeiros, coordinator of the Laboratory of Seed Analysis, for providing the space and equipment for the experiment.

\section{REFERENCES}

BORTOLINI, M. F.; FORTES, A. M. T. Efeitos alelopáticos sobre a germinação de sementes de soja (Glycine max L. Merrill). Semina: Ciências Agrárias, Londrina, v. 26, n. 1, p. 5-10, 2005.

BRASIL. Regras para análise de Sementes. Ministério da Agricultura, Pecuária e Abastecimento, Brasília, 399 p., 2009.

CARVALHO, G. J.; ANDRADE, L. A. B.; GOMIDE, M.; FIGUEIREDO, P. A. M. Potencialidades alelopáticas de folhas verdes + ponteiro de cana-de açúcar em diferentes concentrações de matéria seca, na germinação de sementes de alface. Ciências, Marília, v. 5, n. 2, p. 19-24, 1996.

COELHO, F. M.; OLIVEIRA, S. G.; BALIZA, D. P.; CAMPOS, A. N. R. Efeito de extratos de plantas espontâneas na germinação e no crescimento inicial do feijão comum. Revista Brasileira de Agroecologia, v. 9, n. 2, p. 185-192, 2014.

COSTA, A. F.; VALE, L. S.; OLIVEIRA, A. B.; BRITO NETO, J. F.; RIBEIRO, W. S.; CARDOSO, G. D. Evaluation of yield performance in cowpea genotypes (Vigna unguiculata (L.) Walp.). Australian Journal of Crop Science, v. 11, n. 3, p. 308-312, 2017.

FERREIRA, A. G.; ÁQUILA, M. E. A. Alelopatia: uma área emergente da ecofisiologia. Revista Brasileira de Fisiologia Vegetal, Campinas, v. 12, edição especial, p. 175-204, 2000.

FISHER, H. H. Conceito de erva daninha. In: WARREN, G. F.; WILLIAN, R. D.; SACCO, J. da C.; LAMAR, R. V.; ALBERT, C. A. Curso intensivo de controle de ervas daninhas. Viçosa: UFV, p. 5-10, 1973.

FREIRE FILHO, F. R. Feijão-caupi no Brasil: produção, melhoramento genético, avanços e desafios. Teresina: Embrapa Meio-Norte, 84 p, 2011.

FRITZ, D.; BERNARDI, A. P.; HAAS, J. S.; ASCOLI, B. M.; BORDIGNON, S. A. D. L.; VON POSER, G. Germination and growth inhibitory effects of Hypericum myrianthum and $\mathrm{H}$. polyanthemum extracts on Lactuca sativa L. Revista Brasileira de Farmacognosia, Curitiba, v. 17, n. 1, p. 44-48, 2007.

FROTA, K. D. M. G.; SOARES, R. A. M.; ARÊAS, J. A. G. Composição química do feijão caupi (Vigna unguiculata L. Walp), cultivar BRS-Milênio. Ciência e Tecnologia de Alimentos, Campinas, v. 28, n. 2, p. 470-476, 2008.

FROTA, K. M. G.; MENDONÇA, S.; SALDIVA, P. H. N.; CRUZ, R. J.; AREAAS, J. A. G. Cholesterol-lowering properties of whole cowpea seed and its protein isolate in hamsters. Journal of Food Science, Chicago, v. 73, n. 9, p. H235-H240, 2008. DOI: https://doi.org/10.1111/j.1750-3841.2008.00953.x

GUSMAN, G. S.; YAMAGUSHI, M. Q.; VESTENA, S. Potencial alelopático de extratos aquosos de Bidens pilosa L., Cyperus rotundus L. e Euphorbia heterophylla L. Iheringia Série Botânica, Porto Alegre, v. 66, n. 1, p. 87-98, 2011.
JAKELAITIS, A.; FERREIRA, L. R.; SILVA, A. A.; AGNES, E. L.; MIRANDA, G. V.; MACHADO, A. F. L. Efeitos de sistemas de manejo sobre a população de tiririca. Planta daninha, Viçosa, v. 21, n. 1, p. 89-95, 2003.

KARAM, D.; MELHORANÇA, A. L. Plantas Daninhas. In: CRUZ, J. C.; VERSIANI, R. P.; FERREIRA, M. T. R. (Ed.). Cultivo do milho. Sete Lagoas: EMBRAPA Milho e Sorgo. Sistema de produção. 2007.

LABOURIAU, L. G.; AGUDO, M. On the physiology of seed-germination in salvia-hispanica 1. 1. Temperature effects. Anais da Academia Brasileira de Ciências, Rio de Janeiro, v. 59, n. 1-2, p. 37-56, 1987

MAGUIRE, J. D. Speed of germination-aid in selection and evaluation for seedling emergence and vigor. Crop science, London, v. 2, n. 2, p. 176-177, 1962.

MAIRESSE, L. A. S.; COSTA, E. C.; FARIA, J. R.; FIORINS, R. A. Bioatividade de extratos vegetais sobre alface (Lactuca sativa L.) Revista da FZVA, Uruguaiana, v. 14, n. 2, p. 1-12, 2007.

MARASCHIN-SILVA, F.; AQÜILA, M. E. A. Potencial alelopático de espécies nativas na germinação e crescimento inicial de Lactuca sativa L. (Asteraceae). Acta Botânica Brasílica, Belo Horizonte, v. 20, n. 1, p. 61- 69, 2006.

MAZZAFERA, P. Efeito alelopático do extrato alcoólico do cravo-da-índia e eugenol. Revista Brasileira de Botânica, São Paulo, v. 26, n. 2, p. 231-238, 2003.

MELHORANÇA FILHO, A. L.; PEREIRA, M. R. R.; MARTINS, D. Efeito de subdoses de glyphosate sobre a germinação de sementes das cultivares de soja RR e convecional. Bioscience Journal, Uberlândia, v. 27, n. 5, p. 686-691, 2011

MILES, J. E.; KAWABATA, O.; NISHIMOTO, R. K. Modeling purple nutsedge sprouting under soil solarization. Weed science, Lawrence, v. 50, n. 1, p. 6471, 2002. DOI: https://doi.org/10.1614/00431745(2002)050[0064:MPNSUS]2.0.CO;2

OLIVEIRA, S. C. C.; FERREIRA, A. G.; BORGHETTI, F. Efeito alelopático de folhas de Solanum lycocarpum A. St.-Hil. (Solanaceae) na germinação e crescimento de Sesamum indicum L. (Pedaliaceae) sob diferentes temperaturas. Acta Botanica Brasilica, Belo Horizonte, v. 18, n. 3, p. 401-406, 2004.

PÁDUA, G. P.; ZITO, R. K.; ARANTES, N. E.; NETO, J. B. F. Influência do tamanho da semente na qualidade fisiológica e na produtividade da cultura da soja. Revista Brasileira de Sementes, v. 32, n. 3, p. 09-16, 2010.

PIÑA-RODRIGUES, F. C. M.; LOPES, B. M. Potencial alelopático de Mimosa caesalpinaefolia Benth sobre sementes de Tabebuia alba (Cham.) Sandw. Floresta e Ambiente, Rio de Janeiro, v. 8, n. 1, p. 130-136, 2001.

SCHEREN, M. A.; RIBEIRO, V. M.; NOBREGA, L. H. P. Efeito alelopático de Cyperus rotundus L. no desenvolvimento de plântulas de milho (Zea mays L.). Revista Varia Scientia Agrária, v. 4, n. 1, p. 105-116, 2014.

SILVA, D. V.; FREITAS, M. A. M.; SILVA, G. S.; SOUZA, M.F.; SILVA, A. A.; FERREIRA, L. R.; SEDIYAMA, T.; CECON, P. R. Crescimento e rendimento do milho sob interferência da tiririca. Semina: Ciências Agrárias, Londrina, v. 36, $\mathrm{n}$.5, p. 3077-3084, 2015. DOI: https://doi.org/10.5433/1679-0359.2015v36n5p3077 
SILVA, J.; FORTES, A. M. T.; GOMES, F. M.; PINTO, T. T.; BONAMIGO, T.; BOIAGO, N. P. Alelopatia de Camelina sativa Boiss. (Brassicaceae) sobre a germinação e desenvolvimento inicial de Bidens pilosa (L.) e Glycine $\max ($ L.) Merr. Biotemas, Florianópolis, v. 24, n. 4, p. 17-24, 2011. DOI: https://doi.org/10.5007/2175-7925.2011v24n4p17

SOUZA, W. W. O.; OLIVEIRA, A. B.; DUTRA, A. S.; NUNES, R.L.C.; CAVALCANTE, R. A. Agronomic evaluation of cowpea as a function of weed control with herbicides and different combinations. Revista Ciência Agronômica, Fortaleza, v.47, n. 4, p. 675-682, 2016.

SOUZA FILHO, A. P. S.; BORGES, F. C.; SANTOS, L. Análise comparativa dos efeitos alelopáticos das substâncias químicas titonina e titonina acetilada. Planta Daninha, Viçosa, v. 24, n. 2, p. 205-210, 2006.

ZANARDI, B.; TORQUATO, A. S.; LUZ, E. M. Z.; KAEFER, L. A. P.; FORTES, A. M. T. Alelopatia do extrato de amoreira-negra (Morus nigra L., (MORECEAE) sobre sementes de milho (Zea mays), Revista UNINGÁ Review, v. 26, n. 2, p. 05-09, 2016. 